Tropical Journal of Pharmaceutical Research, December 2002; 1 (2): 75-82

(c) Pharmacotherapy Group,

Faculty of Pharmacy, University of Benin

Benin City, Nigeria.

All rights reserved.

Available online at http://www.tjpr.freehosting.net

\title{
The Quality of Groundwater in Benin City: A baseline study on inorganic chemicals and microbial contaminants of health importance in boreholes and open wells
}

\author{
Patrick O Erah ${ }^{1}$, Christopher N Akujieze ${ }^{2}$ and Gabriel E Oteze ${ }^{2}$ \\ ${ }^{1}$ Pharmacotherapy Group, Faculty of Pharmacy, University of Benin, Benin City, Nigeria. E-mail: erah@uniben.edu, \\ Tel: +234 $8023360318 ;{ }^{2}$ Department of Geology, Faculty of Science, University of Benin, Benin City, Nigeria
}

\begin{abstract}
Purpose: Inorganic chemicals and microorganisms are common in human environments and at high levels poisoning from the chronic effects have occasionally occurred. The purpose of this study was therefore to investigate whether the levels of inorganic chemicals and microbial contaminants in boreholes and open wells in selected Districts in Benin City are sufficient to affect the health of the inhabitants of the areas under investigation.

Method: Six (6) boreholes and three (3) open wells were randomly selected from two Districts (Okhoro and Teboga) in Benin City. Water samples were collected from the boreholes and open wells using standard techniques. Lead (Pb), chromium (Cr), zinc ( $\mathrm{Zn})$, and cadmium (Cd) concentrations as well as aerobic bacteria, presumptive faecal coliform, E. coli, faecal Streptococci and fungi in the water samples were determined using standard procedures. World Health Organisation acceptable limits for drinking water were used in the evaluation.

Result: All the boreholes and open wells were contaminated with abnormal levels of $\mathrm{Pb}$. High levels of $\mathrm{Cr}$ and $\mathrm{Cd}$ were found in the borehole and open wells at Okhoro. Abnormal levels of Zn concentrations were detected in almost all the boreholes and open wells. All the boreholes at Teboga were contaminated with unacceptable levels of aerobic bacteria and fungi. Presumptive faecal colifom, E.coli and faecal Streptococci were seen in all the boreholes.

Conclusion: Some boreholes and open wells in Okhoro and Teboga Districts in Benin City are contaminated with abnormal levels of metals and microorganisms capable of causing health hazards to the consumers of boreholes and open wells.
\end{abstract}

Keywords: Benin City, boreholes, inorganic chemicals, microorganisms, open wells.

${ }^{2}$ To whom correspondence should be addressed: E-mail: akujieze@yahoo.com 


\section{Introduction}

The quality of groundwater is a function of natural processes as well as anthropogenic activities $^{1}$. As the population of Benin City continues to rise (now estimated to be about 1.2 million; figure projected from 1963 population figures), human activities including soil fertility remediation, indiscriminate refuse and waste disposal, and the use of septic tanks, soak-away pits and pitlatrines are on the increase. These activities are capable of producing leachates into the groundwater formation that serve as source of water to the inhabitants in the City.

Previous studies have shown possible contamination of groundwater in the City. In 1992, Imeokparia and Offor $^{2}$ observed the high level of iron $(\mathrm{Fe})$, lead $(\mathrm{Pb})$, nickel $(\mathrm{Ni})$, manganese $(\mathrm{Mn})$, and copper $(\mathrm{Cu})$ in Ogba and Ikpoba Rivers in Benin City. High level of $\mathrm{Fe}$ has also been reported ${ }^{3}$ to be present in some borehole waters in the City. Studies ${ }^{4}$ on Ikpoba Dam Reservoir (which is the major source of public water supply to about $30 \%$ of the inhabitants of Benin City) identified anomalous $\mathrm{Pb}$ concentrations in the gills and muscles of Tilapia marcae (Boulenger) and Chromidotilapia giventheri (Sauvage) fishes.

In the last three years, the sale of packaged water popularly referred to as "pure water" has experienced a tremendous increase. Despite the current efforts being made by the National Agency for Food and Drug Administration and Control (NAFDAC) to sanitize the situation, "pure water" is being produced by many unauthorized sources without appropriate quality control. This has frequently led to raids and destruction of the identified unlicensed packaged water in various parts of the country by NAFDAC (National Television Daily News, 2002) and poses some danger to the communities where the water is consumed. The consumption of bacterial infected water and water contaminated by some metals has dare consequences on the health of the consumers. For example, in 1989 tens of millions of people were believed to be drinking arsenic-rich water in West Bengal, India and Bangladesh with as many as 200,000 people in West Bengal estimated to have been poisoned ${ }^{5}$. The incidence of groundwater contamination by naturally occurring arsenic has also been reported in other countries including Mexico, Chile, Argentina, Mongolia, Ghana and Taiwan ${ }^{5,6}$.

The main purpose of this study therefore is to investigate whether the levels of inorganic chemicals and microbial contaminants in boreholes and open wells in selected Districts in Benin City are sufficient to affect the health of the inhabitants of the City. We hope to be able to determine the (1) level of contamination of boreholes and open wells by inorganic chemicals of health importance and (2) presence of microbial contaminants in the groundwater in selected Districts in Benin City.

\section{Experimental}

Location of study site and hydrogeological setting

This study was carried out in Benin City between November 2001 and November 2002. The City is the capital of Edo State, Nigeria and is located in the south-south geopolitical zone of Nigeria; bounded by latitudes $6^{\circ} 06^{\prime} \mathrm{N}, 6^{\circ} 30^{\prime} \mathrm{N}$ and longitudes $5^{\circ}$ $30^{\prime} \mathrm{E}, 5^{\circ} 45^{\prime} \mathrm{E}$ and area of about 500 square kilometers. The major business in the city is transportation and petty trading. However, there are two brewing factories, furniture factories, four small-scale pharmaceutical production factories, a petroleum storage depot and oil pipeline, and metal works, colour photo laboratories, and a battery assembly factory.

Benin City falls within the tropical equatorial zone dominated by dry season (November March) and wet seasons (April - October). The City is underlain by sedimentary formation described by Short and Stauble ${ }^{y}$. The formation is made up of top reddish 
clayey sand capping highly porous fresh water bearing loose pebby sands, and sandstone with local thin clays and shale interbeds which are considered to be of braided stream origin. Sands, sandstones and clays vary in colour from reddish brown to pinkish yellow on weathered surfaces to white in the deeper fresh surfaces. Limonitic coatings are responsible for the brown reddish-yellowish colour. The formation is covered with loose brownish sand (quaternary drift) varying in thickness and is about $800 \mathrm{~m}$ thick; almost all of which is water bearing with water level varying from about $20 \mathrm{~m}$ to $52 \mathrm{~m}$. It is generally believed to be highly permeable, porous and prolific in water yield. The aquifer yields range from $28.4 \mathrm{~m}^{3} \mathrm{hr}^{-1}$ at Iyanomo (south of the City), $125 \mathrm{~m}^{3} \mathrm{hr}^{-1}$ at Uselu (central part) to $208 \mathrm{~m}^{3}$ $\mathrm{hr}^{-1}$ at Ogba (northern part) with a draw down ranging from $4.8 \mathrm{~m}$ at lyanomo, $1.8 \mathrm{~m}$ at Uselu to $6.7 \mathrm{~m}$ at $\mathrm{Ogba}^{7}$.

\section{Collection of water samples}

We randomly selected two Districts, namely Okhoro in Oredo local government area and Teboga in Ikpoba-Okha local government areas, out of the thirty-three Districts in Benin City. The Districts were selected after geological mapping of the entire City. The two Districts were then in turn geographically mapped and all the boreholes and open wells were identified. Three (3) borehole sites were then selected at random from each of the Districts. Also, three (3) open well sites were selected at random from Okhoro. The random selection was computer generated having identified and assigned codes to all the boreholes and open well sites available in the areas. Groundwater samples were collected from each of the selected sites using downhole submersible electrical pumps as previously described ${ }^{8}$. At least two well volumes were removed before samples were taken. Samples for microbial analyses were immediately filled into sterile glass bottles and sealed. The samples for analyses of dissolved metals were filtered and filled into 2L PVC bottles previously soaked in $10 \%$ nitric acid and rinsed with de- ionised water. All samples were labeled and stored in iced coolers $\left(0-4^{\circ} \mathrm{C}\right)$ in which the samples were taken to the laboratory where analyses were done within $24 \mathrm{hr}$ of sample collection.

\section{Determination of concentrations of metals}

The concentrations of chromium ( $\mathrm{Cr}$ ) was determined colorimetrically using a Spectronic 21D spectrophotometer (Spectronic, Rochester, New York) as previously described $^{9},{ }^{10}$. Cadmium (Cd), lead $(\mathrm{Pb})$ and Zinc were determined with Perkin Elmer atomic absorption spectrophotometer using standard procedures ${ }^{11,12}$. In determining the quality of the groundwater, World Health Organization (WHO) permissible limits ${ }^{13,14}$ were applied.

\section{Determination of microbial contamination}

The presence of aerobic bacterial, presumptive faecal coliform, Eschericia coli, faecal Streptococci and fungi in the water samples collected from the boreholes were evaluated using standard procedures ${ }^{15-17}$. Briefly stated, each water sample was vigorously shaken and $0.1 \mathrm{ml}$ aseptically withdrawn and spread on each nutrient agar (NA) plate, blood agar (BA) plate and solidified potatoes dextrose agar (SPDA), in duplicates. The agar plates were incubated at ambient temperature of $25^{\circ}-27^{\circ} \mathrm{C}$ for 48 $\mathrm{hr}$ (NA plates) or $72 \mathrm{hr}$ (SPDA plates) and at $37^{\circ} \mathrm{C}$ for $24 \mathrm{hr}$ (NA plates) or $72 \mathrm{hr}$ (BA plates). For presumptive coliform, multiple fermentation tubes containing MacConkey broth were inoculated with $10 \mathrm{ml}$ (for double strength broth) and $1 \mathrm{ml}$ or $0.1 \mathrm{ml}$ (for single strength broth) and incubated at $37^{\circ} \mathrm{C}$ for 24 $\mathrm{hr}$ (coliform count) or at $44^{\circ} \mathrm{C}$ for $48 \mathrm{hr}$ ( $E$. coli count). Aerobic bacteria were subjected to further identification as earlier reported ${ }^{18}$.

The total viable aerobic count (dry surface plate count method), total coliform count (multiple tube fermentation technique), faecal Streptococci as well as E. coli counts were evaluated as standard techniques ${ }^{15-17}$. Fungal growth was identified both 
Erah \& et al

microscopically and through the aid of an Atlas of mycology ${ }^{19}$.

\section{Results \\ Inorganic Contaminants in boreholes and open wells}

The concentration of the inorganic chemicals in the different boreholes and open wells are given in Table 1. Both the boreholes and open wells were found to be contaminated with high levels of lead $(\mathrm{Pb})$, chromium $(\mathrm{Cr})$, zinc ( $\mathrm{Zn})$ and cadmium (Cd). In the boreholes, $\mathrm{Pb}$ concentrations were generally as much as 3 to 20 times the acceptable

Table 1: Concentrations (mg/L) of metals in selected boreholes and open wells in Benin City

\begin{tabular}{lcccc}
\hline & $\mathrm{Pb}$ & $\mathrm{Cr}$ & $\mathrm{Zn}$ & $\mathrm{Cd}$ \\
\cline { 2 - 5 } Site & $(0.01)$ & $(0.05)$ & $(3.00)$ & $(0.003)$ \\
\hline Boreholes & & & & \\
Okhoro - 1 & 0.03 & 0.27 & 7.19 & 0.11 \\
Okhoro - 2 & 0.20 & 1.00 & 6.53 & 0.23 \\
Okhoro - 3 & 0.08 & 1.10 & 8.50 & 0.10 \\
Teboga - 1 & 0.08 & 0.02 & 3.27 & 0.02 \\
Teboga - 2 & 0.07 & 0.02 & 2.62 & $\mathrm{ND}$ \\
Teboga - 3 & 0.04 & 0.01 & 2.29 & $\mathrm{ND}$ \\
& & & & \\
Open well & & & & \\
Okhoro - 1 & 0.15 & 1.10 & 1.63 & 0.20 \\
Okhoro - 2 & 0.15 & 0.09 & 5.23 & 0.08 \\
Okhoro-3 & 0.25 & 0.08 & 0.98 & 0.10 \\
\hline Values in parentheses are the World Health & prested \\
Organisation permissible limits; ND, Not detected
\end{tabular}

limits but in open wells the concentrations were as much as 15 to 25 times the acceptable limits. Differences were observed in the levels of $\mathrm{Cr}$ in the waters at Okhoro when compared with the levels found at Teboga. Chromium levels in the boreholes at Teboga were within acceptable levels while the boreholes at Okhoro had as much as 2 to 5 times the acceptable limits. Also, all the open wells at Okhoro had $\mathrm{Cr}$ levels higher than the acceptable limits. Only 2 of the boreholes and an open well had $\mathrm{Zn}$ levels within the acceptable limits while only 2 boreholes had Cd concentrations within the acceptable limit. The boreholes and open wells at Okhoro had much higher levels of $\mathrm{Cd}$ than the only borehole at Teboga where Cd was detected.

\section{Microbial contaminants in boreholes}

The microbial contaminants identified in the boreholes are given in Table 2. All the boreholes at Teboga were found to be contaminated with unacceptable levels of aerobic bacteria and fungi while only one of the boreholes at Okhoro was contaminated with unacceptable levels of aerobic bacteria. Presumptive faecal colifom, E.coli and faecal Streptococci were found in all the boreholes.

\section{Discussion}

People have always been exposed to inorganic chemicals and microorganisms in their environments and inadvertent poisoning have occasionally occurred ${ }^{6}$. Strictly speaking, pure groundwater does not exist for any appreciable length of time in nature. Even while falling as rain, water picks up small amounts of gases, ions, dust, and particulate matter from the atmosphere. Then, as it flows over or through the surface layers of the earth, it dissolves and carries with it some of almost everything it touches, including that which is dumped into it by man. These added substances may include biological, chemical (both inorganic and organic), physical, and radiological impurities such as industrial and commercial solvents, metal and acid salts, sediments, pesticides, herbicides, plant nutrients, radioactive materials, decaying animal and vegetable matter, and living microorganisms, such as algae, bacteria and viruses ${ }^{20}$. The groundwater may be ultimately discharged from an aquifer as base or spring water to rivers, wetland, estuaries, quarries or springs and the latter may be affected adversely if the groundwater is contaminated ${ }^{1}$. It is the health consequences of drinking the contaminated water that is the major concern in this study. 
Erah \& et al

Table 2: Microbial counts in selected boreholes in Benin City

\begin{tabular}{lccccc}
\hline & \multicolumn{4}{c}{ Total viable count (cfu/ml) } \\
\cline { 2 - 6 } Site & $\begin{array}{c}\text { Aerobic } \\
\text { bacteria }\end{array}$ & $\begin{array}{c}\text { Presumptive } \\
\text { faecal coliform }\end{array}$ & E. Coli & $\begin{array}{c}\text { Faecal } \\
\text { Streptococci }\end{array}$ & Fungi \\
\cline { 2 - 6 } & $(100)$ & $(0)$ & $(0)$ & $(0)$ & $6.0 \times 10^{1}$ \\
\hline Okhoro - 1 & $5.9 \times 10^{1}$ & $4.6 \times 10^{1}$ & 9.0 & $1.2 \times 10^{1}$ & $5.0 \times 10^{1}$ \\
Okhoro-2 & $1.0 \times 10^{1}$ & $9.4 \times 10^{1}$ & $1.7 \times 10^{1}$ & 9.0 & $2.0 \times 10^{1}$ \\
Okhoro-3 & $1.1 \times 10^{2}$ & $2.4 \times 10^{3}$ & $1.4 \times 10^{1}$ & 6.0 & $4.3 \times 10^{3}$ \\
Teboga - 1 & $1.4 \times 10^{5}$ & $2.4 \times 10^{3}$ & $7.0 \times 10^{1}$ & $1.2 \times 10^{1}$ & $1.13 \times 10^{3}$ \\
Teboga - 2 & $4.8 \times 10^{5}$ & $2.4 \times 10^{3}$ & $2.2 \times 10^{2}$ & $3.5 \times 10^{2}$ & $8.3 \times 10^{3}$ \\
Teboga - 3 & $2.5 \times 10^{5}$ & $1.6 \times 10^{3}$ & $1.7 \times 10^{1}$ & $2.1 \times 10^{1}$ & \\
\hline
\end{tabular}

Contaminants in drinking water that have an adverse health impact are grouped into five categories: inorganic chemical contaminants, organic chemical contaminants, microbiological contaminants, radiological contaminants, and turbidity ${ }^{20}$. In this study, the focus on the assessment of the level of contamination of the groundwater and open wells in Benin City has been on the inorganic chemicals and microbiological contaminants because of the major concern of the impact of these two categories on the health of the inhabitants of the City as previous studies ${ }^{1-3}$ have shown the presence of contaminants in the groundwater available in the area.

\section{Inorganic contaminants}

Generally, toxic chemicals in drinking water may cause either acute or chronic health effects. Acute effects such as nausea, lung irritation, skin rash, vomiting, dizziness, and, in the extreme, death usually follow large doses of chemicals and occur almost immediately. It is recognized that the levels of inorganic chemicals in drinking water are seldom high enough to cause acute health effects $^{20}$. Chronic effects, like cancer, birth defects, organ damage, disorders of the nervous system, and damage to the immune system, are usually more common.
The supply of portable water is usually the responsibility of the government. However, inadequate funds have always been blamed by successive governments in Edo State (where Benin City is located) for inability to meet the basic needs of the populace including adequate supply of portable water. Only an estimated $30 \%$ of the inhabitants of Benin City may sometimes get water supply from the public water supply. The rest $70 \%$, and even those who get drinking water from the public water supply, rely heavily on supplies from private boreholes and open wells. Unfortunately, proper treatment of the water before being delivered for use as drinking water is not considered by many of the drinking water sources. This exposes the inhabitants using the untreated water to the health hazards of the contaminants. Therefore, the abnormally high levels of inorganic chemicals $(\mathrm{Pb}, \mathrm{Cr}, \mathrm{Zn}$ and $\mathrm{Cd}$ ) in the groundwater and open wells observed in this study is of great concern and calls for urgent attention if the inhabitants are to be protected against the chronic effects of the abnormal levels of the chemicals.

$\mathrm{Pb}$ poisoning is rare $^{6}$, but relatively low levels of chronic exposure as is expected in areas investigated in this study can produce adverse health effects that may include 
Erah \& et al

interference in red blood cell chemistry, delays in normal physical and mental development in babies and young children, slight deficits in the attention span, hearing, and learning abilities of children, and slight increases in blood pressure of some adults $^{20}$. Other effects of chronic poisoning by $\mathrm{Pb}$ are gastrointestinal, neuromuscular and renal signs and symptoms such as anorexia, headache, malaise, diarrhoea, lead-palsy, encephalopathy, insomnia, etc. For every $\mu \mathrm{g} / \mathrm{dl}$ increase in blood levels of lead $(\mathrm{Pb})$ within the range of $5-35 \mu \mathrm{g} / \mathrm{dl}$, there is a 2- to 4-point intelligence quotient (IQ) deficit; bad news for children ${ }^{6}$. Chromium exposure at high levels has been shown to result in chronic toxic effects (including liver and kidney damage, internal hemorrhage, and respiratory disorders) in animals and humans by ingestion ${ }^{20}$. Also, chronic exposure to $\mathrm{Cd}$ in animals and humans results in kidney dysfunction, hypertension, anemia, and liver damage, ${ }^{60}$. The kidney is considered to be the critical target organ in humans most susceptible to damage by chronic exposed to $\mathrm{Cd}$ by ingestion. Chronic exposure to $\mathrm{Cd}$ also produces gastrointestinal effects such as nausea, vomiting, salivation, and diarrhoea ${ }^{20}$, ${ }^{21}$ as well as reduction in male fertility ${ }^{22}$. Carcinogenesis due to inhalation of $\mathrm{Cd}$ is well documented $^{20,21}$ but this has not be proven by oral ingestion. Zinc is found in some natural waters, most frequently in areas where it is mined, and can be detrimental to health when it occurs in very high concentrations as observed in this study. It also imparts an undesirable taste to drinking water ${ }^{23}$.

The possible sources of metal contaminants of the boreholes and open wells are uncertain. It is likely due to natural processes and anthropogenic activities ${ }^{1}$. Okhoro area seems to be more contaminated with metals than Teboga as observed by the much higher levels of $\mathrm{Cr}$ and $\mathrm{Cd}$ in Okhoro. The reason for this is difficult to explain at this stage as further studies of more sites in the areas will be necessary.

\section{Microbial contaminants}

The presence of certain microorganisms is often undesirable in any drinking water. When microorganisms are present in water, cycles of growth and decay of the cellular materials of the microorganisms may result in the production of by-products which may adversely affect the quality of the water supply. This is also true regarding the growth cycles of other non-pathogenic bacteria and harmless microorganisms ${ }^{20}$. Drinking waters from the boreholes and open wells in most Districts in Benin City are unlikely to be treated in any way before they are ingested. Thus the presence of pathogenic microorganisms (aerobic bacteria, coliform, faecal Streptococci) and fungi in the boreholes and open wells is a major concern for consumers because of the effect of the microorganisms on the health of consumers. Coliform are a group of bacteria with common characteristics used to indicate unacceptable water quality. Within the total coliform group, the E. coli bacteria are specifically used to indicate faecal contamination.

Boreholes and open wells are sited indiscriminately in Districts in Benin City without proper geological surveys. Indiscriminate refuse and waste disposal and location of septic tanks, soak-away pits and pit-latrines in living surroundings are common. These activities could account for the presence of faecal bacteria in the borehole waters.

Although the result of this study indicates the presence of chemical and microbial contaminants which have health hazard implications, it cannot be assumed that the level of contamination will be the same in all areas in Benin City as seen in the difference between Okhoro and Teboga. It is unlikely that the situation in most other areas in the City will be significantly different as the living standards and activities are similar in most parts of the City which is underlain by the same formation. Therefore there is urgent need for public enlightenment of the 
Erah \& et al

inhabitants of Benin City on the need to treat borehole and open well water before drinking and observe good hygiene. The government must seriously give the desired adequate attention to the supply of portable water to the inhabitants of the City. Routine monitoring of the groundwater and human activities within the City by the relevant government agency should ensure a reduction in the level of pollution of the waters coming from boreholes and open wells.

Further studies will be necessary to determine the prevalence of diseases associated with $\mathrm{Cr}$ and $\mathrm{Cd}$ in Okhoro as the inhabitants are predictably more likely to suffer from hypertension, anemia, liver disease, gastrointestinal diseases and reduced fertility in males than the general population. $\mathrm{Cr}$ and $\mathrm{Cd}$ levels will then be determined in the blood of those identified to suffer from any of the diseases associated with the metals

\section{Conclusion}

Water is life and access to good quality water cannot be overemphasized. Increased human activities in Benin City, particularly the indiscriminate location of septic tanks, soak-away pits and pit-latrines, disposal of refuse and waste, and other materials that can leach into the groundwater constitute a major health concern. Majority of the inhabitants of the City continue to consume water from boreholes and wells without adequate and proper treatment.

The boreholes and open wells in some Districts in Benin City are contaminated with abnormal levels of metals and microorganisms with serious health hazards. This calls for public health education and routine monitoring of human activities in the City. Further investigation is necessary to determine the health implication of the unacceptable levels of heavy metals and microbial contaminants of the groundwater observed in this study.

\section{References}

1. Sajjad MM, Rahim S, Tahir SS. Chemical quality of groundwater of Rawalpindi/Islamabad. Pakistan 24th WEDC Conference, Islamabad, Pakistan, 1998.

2. Imeopkaria EG, Offor N. Heavy metal occurrence in Ikpoba and Ogba River sediments. Paper presented at $10^{\text {th }}$ Annual National Conference of Nigerian Association of Hydrogeologists (NAH), November 1992.

3. Ohagi SQ, Akujieze CN. Iron in borehole water sources in Bendel State, Nigeria. J Nig Assoc of Hydrogeol 1989; 1 (2): 192-6

4. Tawari-Fufeyin P. Heavy metal levels in some dominant fish of Ikpoba reservoir in Benin City. J Env Rev 1998; 2: 61-69.

5. Jacobson $\mathrm{G}$. Arsenic poisoning from groundwater in Bengal: The worst hydrogeological problem in the world. International Association of Hydrogeologist, Issue C19, October 1998, pp 7-8.

6. Klaassen CD. Heavy metals and heavy-metal antagonists. In: Hardman JD, Limbird LE, Gilman AG (eds). The Pharmacological Basis of Therapeutics, 12 edition. New York: McGraw Hill, 2001; pp 1851-75.

7. Short K, Stauble AJ. Outline of the geology of Niger Delta. Am Assoc Petroleum Geologists Bull 1967; 51: 761-79.

8. Wersin $\mathrm{P}$, Abrecht $\mathrm{J}$, Hohener $\mathrm{P}$. Large-scale redox plume in glaciofluvial deposits due to sugarfactory wastes and wastewater at Aarberg, Switzerland. Hydrogeo J 2001; 9: 282-96.

9. Ademoroti CMA. Standard methods for water and effluents analysis. Benin City, Nigeria: Ademoroti CMA (Publisher) 1996.

10. Clescer LS, Greenberg AE, Trussell RR (eds). Standard methods for the examination of water and wastewater. Washington DC: American Public Health Association, 1989.

11. Ferrer L, Contardi E, Andrade SJ, Asteasuain R, Pucci AE, Marcovecchio JE. Environmental cadmium and lead concentrations in the Bah'ia Blanca (Argentina): Potential toxic effects of $\mathrm{Cd}$ and $\mathrm{Pb}$ on crab larvae. Oceanologia 2000; 42(4): 493504.

12. White C. Atomic absorption spectrophotometric determination of zinc and copper in a multivitamin. Athens Technical College, Athens, GA - available at http://www.terrificscience.org/ lessonexchange/PACTPDF/AtomicAbsorption.pdf

13. Guidelines for Drinking Water. Geneva, Switzerland World Health Organization (WHO), 1993.

14. Guidelines for Drinking Water, $2^{\text {nd }}$ edition vol 2. Health criteria and other supporting information. Geneva, Switzerland: World Health Organization (WHO), 1996 pp 940-9; Addendum to vol 2, 1998 pp 281-3.

15. American Public Health Association, American Water Works Association and Water Pollution Control Federation. Standard Methods for the Examination of Water and Wastewater, $18^{\text {th }} \mathrm{Ed}$ Washington, DC, 1992.

81 Trop J Pharm Res, December 2002; 1 


\section{Erah \& et al}

16. American Public Health Association, American Water Works Association and Water Pollution Control Federation. Standard Methods for the Examination of Water and Wastewater, $20^{\text {th }}$ edition, Washington, DC, 1998.

17. Hutton LG. Testing of water in developing countries. In: Hutton LG. Water and Waste Engineering for Developing Countries. Loughbourough, Leicester, UK: Water Research Centre, 1983.

18. Cowna ST, Steel KJ. Manual of the identification of medical bacteria, $2^{\text {nd }}$ ed. Cambridge: Cambridge University Press, 1984.

19. Cowna ST, Steel KJ. Manual of the identification of medical bacteria, $2^{\text {nd }}$ ed. Cambridge: Cambridge University Press, 1984.

20. Rhode B, Hartmann G. Introducing mycology by examples. Schering Aktiengesellschaft, 1980.
21. Shelton TB (ed). Interpreting drinking water quality analysis. What do the number mean? New Jersey, USA: Rutgers Cooperative Extension 2002 - http://www.walrus.com/ gatherer/interpret. html. Downloaded 20/12/02.

22. Waakes MP, Coogan TP, Barter RA. Toxicological principles of metal carcinogenesis with special emphasis on cadmium. Crit Rev Toxicolo 1992; 22: 175-201.

23. Wyrobek AJ, Bruce WR. Chemical induction of sperm abnormalities in mice. Proc Natl Acad Sci USA 1975; 72 : 44254429

24. Environmental Fact Sheet (WD-WSEB-3-8). New Hampshire: Department of Environmental Services, 1998. 